\title{
Pemanfaatan ICT Untuk Pengembangan Perusahaan Kecil dan Menengah di Look at Hijab Bandung
}

\author{
Doni Purnama Alamsyah ${ }^{1}$ \\ 1Universitas BSI, doni.dpa@bsi.ac.id \\ Ani Solihat ${ }^{2}$ \\ 2AMIK BSI Bandung, ani.ani@bsi.ac.id \\ Hendi Suhendi ${ }^{3}$ \\ 3Universitas BSI, handy.hnh@bsi.ac.id \\ Ricky Firmansyah" \\ ${ }^{4}$ AMIK BSI Bandung, ricky.rym@bsi.ac.id \\ Nanang Hunaifi ${ }^{5}$ \\ ${ }^{5}$ AMIK BSI Bandung, nanang.nnu@bsi.ac.id \\ Amirul Mukminin' \\ 6AMIK BSI Bandung, amirul.amk@bsi.ac.id \\ Phitsa Mauliana ${ }^{7}$ \\ 7AMIK BSI Bandung, phitsa.phu@bsi.ac.id \\ Maxsi Ary ${ }^{8}$ \\ 8AMIK BSI Bandung, maxsi.max@bsi.ac.id
}

\begin{abstract}
Abstrak
Peranan ICT sangatlah membantu dalam pekerjaan sehari-hari baik organisasi, perusahaan yang berupa unit kecil ataupun perusahaan besar seperti UMKM. Penggunaan ICT dapat dilakukan dengan membangun website company profile perusahaan. UMKM Look at Hibaj merupakan industri kecil di Kota Bandung yang belum optimal menggunakan ICT, sehingga penelitian fokus pada pengabdian melalui pembangunan website company profile untuk UMKM Look at Hijab. Pembangunan website dilakukan melalui metode pengembangan sistem prototyping. Dengan adanya pemanfaatan ICT, permasalahan di Look at Hijab dapat ditangani dengan baik. Website company profile menjadi salah satu sarana pemasaran yang dapat digunakan oleh Look at Hijab dalam menghadapi persaingan dan pertumbungan UMKM di Kota Bandung.
\end{abstract}

Kata Kunci : ICT, UMKM, Company Profile

\section{Abstract}

The role of ICT is very helpful in the daily work of organizations, companies in the form of small units or large companies such as SMEs. The use of ICT can be done by building company profile company website. SMEs Look at Hijab is a small industry in Bandung that has not been optimally used ICT, so the research focus on devotion through the development 
of company profile website for SMEs Look at Hijab. Website development is done through method of prototyping system development. With the use of ICT, problems at Look at Hijab can be handled well. Website company profile became one of the marketing tools that can be used by Look at Hijab in the face of competition and growth of SMEs in Bandung.

Keywords : ICT, UMKM, Company Profile

\section{Pendahuluan}

Dari perspektif dunia, diakui bahwa usaha Mikro, Kecil dan Menengah (UMKM) memainkan peran yang sangat vital di dalam pembangunan dan pertumbuhan ekonomi, tidak hanya dinegara berkembang, tetapi juga di Negara maju (Rahmi, Rozalia, Chan, Anira, \& Lita, 2017). UMKM sangat penting tidak hanya karena kelompok usaha tersebut menyerap paling banyak tenaga kerja dibandingkan usaha besar, tetapi karena sebagai salah satu penopang perekonomian negara (Hasibuan, 2015). Disamping itu UMKM juga berkontribusi terhadap pembentukan dan pertumbuhan produk domestik bruto (Susilo, 2010). Hal ini menyiratkan arti pentingnya mengedepankan peran UMKM disuatu negara, termasuk di Indonesia. Salah satu UMKM di Kota Bandung yang sedang berkembang dan menjadi Mitra Kerjasama AMIK BSI Bandung adalah Look at Hijab. Namun masih ada kelemahan terkait strategi pemasaran yang belum menggunakan Information and Communication Technologies (ICT). Padahal ICT merupakan suatu alat yang dapat digunakan oleh perusahaan dalam operasionalnya termasuk pemasaran produk (Al-Tabbaa \& Ankrah, 2016).

Look at Hijab merupakan UMKM yang terletak di tengah Kota Bandung. UMKM ini mengalami banyak hambatan, salah satunya adalah kesulitan-kesulitan dalam pemasaran, keterbatasan akses ke informasi mengenai peluang pasar dan lainnya, kesulitan dalam pengelolaan laporan keuangan, keterbatasan pekerja dengan keahlian tinggi (kualitas SDM rendah) dan kemampuan teknologi. Keadaan tersebut tentunya merupakan penghambat dari kemajuan Look at Hijab untuk berkembang. Saat ini tantangan ke depan UMKM untuk mampu bersaing di era perdagangan bebas, baik dipasar domestik maupun di pasar ekspor, sangat ditentukan oleh kemampuan internal UMKM yang harus di perbaiki, mencakup aspek kualitas SDM, terutama penguasaan pemanfaatan teknologi dan informasi, sistem manajemen, kekuatan modal dan jaringan bisnis dengan pihak luar (Urfa, Handayani, \& Hidayat, 2013). Menelaah dari permasalah atas Look at Hijab dengan kondisinya saat ini, dilakukan upaya kerjasama antara AMIK BSI Bandung dengan Look at Hijab dalam kerangka Pengabdian kepada Masyarakat. Hal ini yang menjadi fokus kajian pada penelitian ini yaitu kajian atas pemanfaatan ICT untuk pengembangan UMKM di Look at Hijab.

\section{Fenomena Masalah Pada Look at Hijab}

Sebelum dilakukan kajian atas pemanfaat ICT untuk UMKM yaitu Look at Hijab, dilakukan kajian atas fenomena masalah. Fenomena masalah dikumpulkan melalui wawancara. Berdasarkan hasil wawancara dengan pengurus dan anggota, diperoleh informasi bahwa UMKM Look at Hijab sedang berada dalam kondisi belum menggunakan Teknologi Informasi dalam strategi pemasaran, nampak dari tidak 
adanya website atau strategi pemasaran melalui media sosial. Disamping itu, sistem pengelolaan pada UMKM masih menggunakan metode tradisional. Nampak dari pengelolaan SDM dan Keuangan masih dibuat secara manual pada buku besar atau catatan-catatan kecil. Pada perasional UMKM nampak kondisi perangkat kerja belum menggunakan Teknologi Informasi. Hal tersebut dikarenakan belum adanya sistem yang terkomputerisasi dengan baik serta kemampuan pengurus UMKM yang terbatas. Berbagai kondisi atas LookAt Hijab saat ini yaitu aktivitas di UMKM sangat tidak efisien dan efektif, serta terkendala dalam eksistensi UMKM untuk dikenal oleh masyarakat. Berdampak pada lambatnya proses pengembangan keberhasilan dari UMKM untuk dapat bersaing dengan UMKM yang lain.

Menelaah dari fenomena masalah atas Look at Hijab, maka dilakukan kajian pemanfaatan ICT melalui pembangunan company profile UMKM. Sistem informasi yang dikembangkan, diharapkan mampu memfasilitasi pengurus UMKM Look at Hijab untuk meningkatkan kinerja serta sebagai media informasi publik agar lebih dikenal Look at Hijab membutuhkan adanya perbaikan sistem yang lebih baik untuk meningkatkan kinerja dan eksistensi UMKM ini. Berdasarkan analisis situasi, dapat teridentifikasi beberapa permasalahan yang dihadapi oleh mitra, yaitu:

a. Rendahnya efektifitas dan efisiensi kerja pengurus UMKM dalam mengelola UMKM.

b. Belum optimalnya fungsi perangkat komputer yang sudah untuk mampu terintegrasi satu dan lainnya yang dapat mempercepat kinerja diantara unit kerja UMKM.

c. Belum tersedianya media informasi publik yang dapat diakses dengan mudah oleh anggota untuk turut serta memantau kinerja UMKM.

d. Kurangnya aktivitas promosi dan penyebaran informasi kepada masyarakat terkait dengan aktivitas bisnis UMKM.

\section{Website melalui Company Profile}

Website sering juga disebut Web, dapat diartikan suatu kumpulan-kumpulan halaman yang menampilkan berbagai macam informasi teks, data, gambar diam ataupun bergerak, data animasi, suara, video maupun gabungan dari semuanya, baik itu yang bersifat statis maupun yang dinamis (Suhartanto, 2012). Website bekerja membentuk satu rangkaian bangunan yang saling berkaitan dimana masingmasing dihubungkan dengan jaringan halaman atau hyperlink. Website juga dikatakan sebagai kumpulan dari berbagai macam halaman situs, yang terangkum didalam sebuah domain atau juga subdomain, yang lebih tempatnya berada di dalam WWW (World Wide Web) yang tentunya terdapat di dalam Internet (Pontoh \& Lumenta, 2016).

Halaman website biasanya berupa dokumen yang ditulis dalam format Hyper Text Markup Language (HTML), yang bisa diakses melalui HTTP. HTTP adalah suatu protokol yang menyampaikan berbagai informasi dari server website untuk ditampilkan kepada para user atau pemakai melalui web browser (Pendong, Molenaar, Wullur, \& Pinatik, 2015). Website memiliki beberapa jenis, artinya pemanfaatan website tergantung dari jenis yang akan digunakan. Jenis-jenis website ada 3 (tiga) macam diantaranya (Prasetyo, 2015): 
a. Website Statis adalah suatu website yang mempunyai halaman yang tidak berubah. Yang artinya adalah untuk melakukan sebuah perubahan pada suatu halaman hanya bisa dilakukan secara manual yaitu dengan cara mengedit kodekode yang menjadi struktur dari website itu sendiri.

b. Website Dinamis adalah merupakan suatu website yang secara strukturnya diperuntukan untuk update sesering mungkin. Biasanya selain dimana utamanya yang bisa diakses oleh para pengguna (user) pada umumnya, juga telah disediakan halaman backend yaitu untuk mengedit konten dari website tersebut. Contoh dari website dinamis seperti web berita yang didalamnya terdapat fasilitas berita.

c. Website Interaktif adalah suatu website yang memang pada saat ini memang terkenal. Contohnya website interaktif seperti forum dan blog. Di website ini para pengguna bisa berinteraksi dan juga beradu argumen mengenai apa yang menjadi pemikiran mereka.

Salah satu manfaat dari website adalah terciptanya company profile (Reilly \& Hynan, 2014). Company profile dapat dibuat baik statis, dinamis maupun interaktif, sesuai kebutuhan dari perusahaan. Company profile adalah sebuah aset suatu lembaga atau perusahaan yang biasa digunakan sebagai tanda pengenal dalam melakukan komunikasi yang baik dan kerjasama dalam lingkup intern perusahaan maupun dengan kolega, mitra usaha ataupun pihak-pihak terkait lainnya diluar lingkungan perusahaan tersebut (Aris, Saputra, Macario, Maulana, \& Mustaqim, 2015). Nampak bahwa company profile memiliki beberapa keunggukan untuk perusahaan, salah satunya sebagai media pemasaran memperkenalkan perusahaan kepada masyarakat luas. Tidak jarang company profile diciptakan oleh perusahaan guna meningkatkan citra perusahaan (brand) (Kapoor \& Sandhu, 2010).

\section{Metode Penelitian}

Pembuatan company profile pada Look at Hijab dilakukan dengan bertahap, dimana dimulai dari pengumpulan data penelitian sampai perancangan website company profile. Pengumpulan data dilakukan melalui pengamatan secara langsung pada Objek penelitian dan pengabdian yaitu UMKM Look at Hijab. Wawancara mendalam dengan pemilik UMUM dan kajian atas pustaka penelitian terdahulu. Adapun selanjutnya dilakukan perancangan website company profile melalui metode pengembangan sistem Prototipe (Aswati, Ramadhan, Firmansyah, \& Anwar, 2017). Berikut gambaran dari tahapan pengembangan sistem company profile Look at Hijab (Gambar 1). 


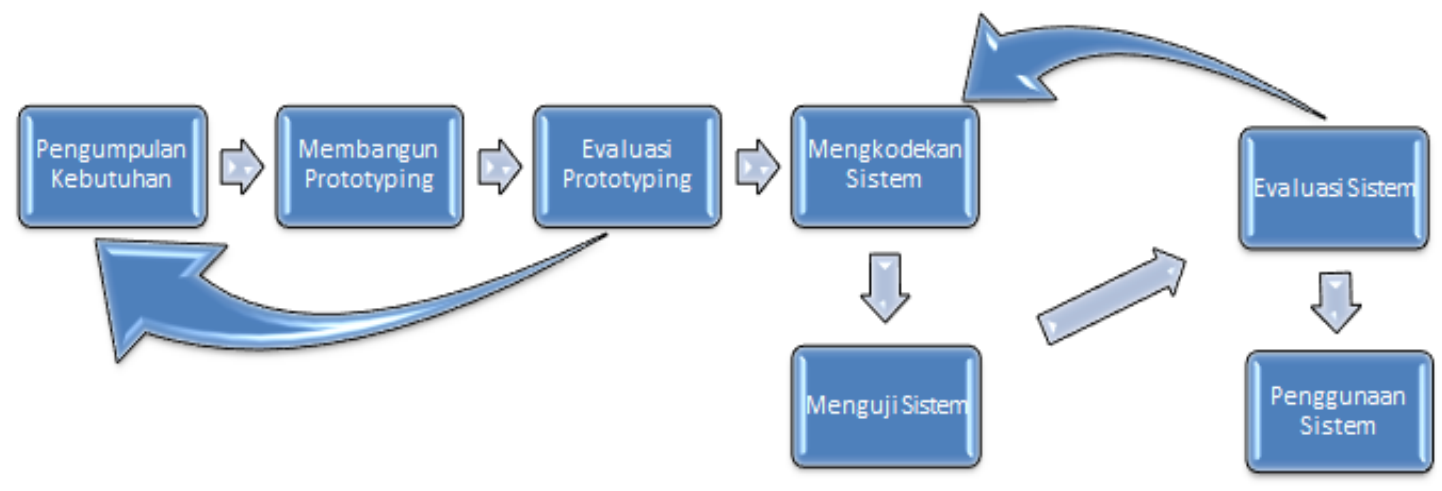

Gambar 1. Prototyping Model

Tahapan-tahapan dalam prototyping model adalah sebagai berikut:

a. Pengumpulan kebutuhan

Pelanggan dan pengembang bersama-sama mendefinisikan format seluruh perangkat lunak, mengidentifikasikan semua kebutuhan, dan garis besar sistem yang akan dibuat.

b. Membangun prototyping

Membangun prototyping dengan membuat perancangan sementara yang berfokus pada penyajian kepada pelanggan (misalnya dengan membuat input dan format output).

c. Evaluasi protoptyping

Evaluasi ini dilakukan oleh pelanggan apakah prototyping yang sudah dibangun sudah sesuai dengan keinginann pelanggan. Jika sudah sesuai maka langkah 4 akan diambil. Jika tidak prototyping direvisi dengan mengulang langkah 1, 2, dan 3.

d. Mengkodekan sistem

Dalam tahap ini prototyping yang sudah di sepakati diterjemahkan ke dalam bahasa pemrograman yang sesuai.

e. Menguji sistem

Setelah sistem sudah menjadi suatu perangkat lunak yang siap pakai, harus dites dahulu sebelum digunakan. Pengujian ini dilakukan dengan White Box, Black Box, Basis Path, pengujian arsitektur dan lain-lain.

f. Evaluasi Sistem

Pelanggan mengevaluasi apakah sistem yang sudah jadi sudah sesuai dengan yang diharapkan. Jika ya, langkah 7 dilakukan; jika tidak, ulangi langkah 4 dan 5.

g. Menggunakan sistem

Perangkat lunak yang telah diuji dan diterima pelanggan siap untuk digunakan.

\section{Hasil dan Pembahasan}

Hasil penelitian dan pembasahan yang dilakukan pada pengabdian masyarakat di Look at Hijab, disampaikan melalui kajian prototyping model. Setelahnya diakhiri dengan terciptanya website company profile dari UMKM Look at Hijab. 


\section{Pengumpulan kebutuhan}

Tahap pertama dari pengabdian yang dilakukan adalah pengumpulan data sebagai kebutuhan untuk membangun website. Beberapa data yang berhasil dikumpulkan diantaranya struktur organisasi, data SDM, data produk, data Keuangan, data pemasaran dan data konsumen. Data lain yang juga dikumpulkan adalah informasi konsumen berupa komentar dan survey kepuasan konsumen. Data yang berhasil dikumpulkan selajutnya diseleksi sebagai master data untuk membangun website company profile dari Look at Hijab.

\section{Membangun prototyping}

Membangun prototyping dengan membuat perancangan sementara yang berfokus pada penyajian kepada konsumen dan masyarakat luas. Berikut gambaran dari perancangan sementara (Gambar 2).

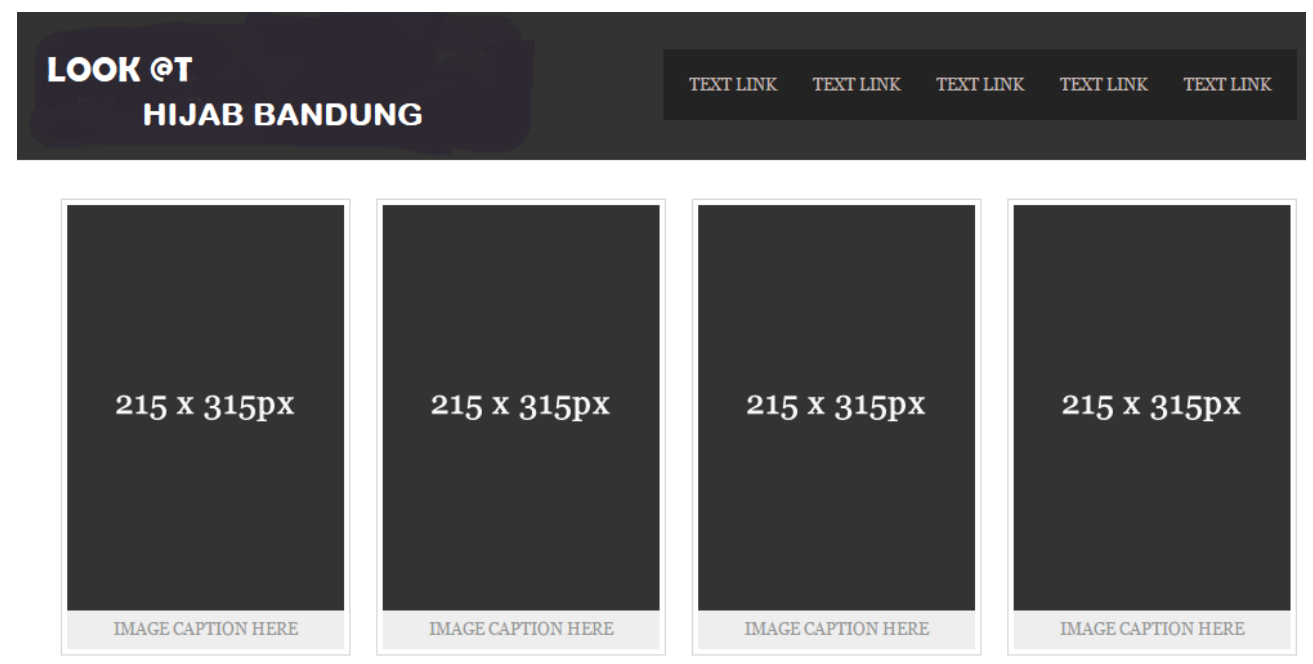

Gambar 2. Tampilan Home Website Look at Hijab

Dari gambaran yang disampaikan pada Gambar 2, nampak bahwa terdapat main judul utama dalam "text link" sebanyak 5 (lima) item dan tampilan pilihan utama sebesar $215 \times 315$ px (pixel) masing-masing tampilan. Hal ini menandakan bahwa informasi utama yang akan disampaikan oleh UMKM Look at Hijab terdapat 5 (lima) bahasan. Pada setiap masing-masing informasi utama terdiri dari maksimum 4 (empat) tampilan informasi yang bisa disampaikan oleh Look at Hijab.

\section{Evaluasi protoptyping}

Prototyping telah selesai dibangun dan disampaikan kepada pengguna yaitu UMKM Look at Hijab. Terdapat 5 (lima) menu utama yang tercipta yaitu Home, Lookathijab, Artikel, Berita, Produk dan Kontak. Pada bagian utama website terdapat penjelasan dari masing-masing menu utama yang dibuat secara sederhana agar mudah dipahami pengguna. Hasil secara keseluruhan website company profile Look at Hijab dinilai baik oleh pengguna. Sehingga langkah selanjutnya dilakukan pembangunan website melalui pengkodean sistem. 


\section{Mengkodekan sistem}

Pada tahap ini telah dilakukan kesepakatan atas prototyping yang akan dibuat, terjadi beberapa perubahan atas tampilan prototyping. Namun disinilah fungsi dari metode prototyping yaitu membuat pengembangan sistem dengan tahapan pembuatan uji coba melalui prototyping. Tujuan dari tahapan ini guna mencegak pengembangan sistem diluar keinginan dari pengguna yaitu UMKM Look at Hijab. Pengkodeaan dilakukan guna membangun website company profile sampai penerbitan website secara online. Tentunya hal ini dilakukan untuk menguji sistem dari website company profile.

5. Menguji sistem

Pada tahap ini pembuatan website sudah selesai dan sudah publish secara online dengan nama www.lookat-hijab.com. Langkah selanjutnya dilakukan pengujian sistem dengan metode White Box, Black Box, Basis Path, dan pengujian arsitektur. Hasil untuk semua uji dikatakan baik, artinya bahwa tidak ada kendala dari website company profile Look at Hijab.

6. Evaluasi Sistem

Setelah sistem terbangun yaitu website company profile Look at Hijab, dilakukan evaluasi dengan indikator yang digunakan untuk evaluasi sistem yaitu kualitas sistem, kualitas informasi dan kualitas layanan pada sistem (Krisbiantoro, Suyanto, \& Taufiqluthfi, 2015). Berikut hasil evaluasi dalam grafik evaluasi sistem pada Gambar 3.

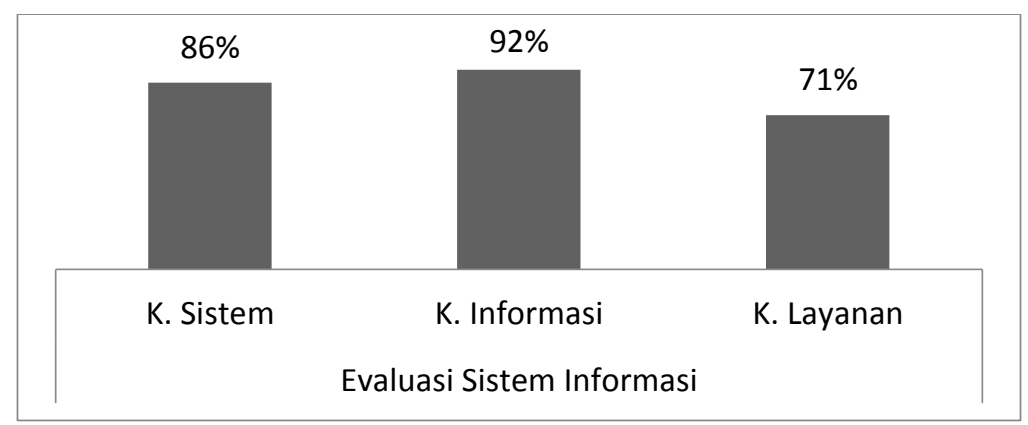

Gambar 3. Evaluasi Sistem Informasi Company Profile

Berdasarkan penilaian dari pengguna yaitu semua karyawan dari UMKM Loot at Hijab di Bandung dan 20 konsumen Look at Hijab. Diketahui hasilnya bahwa kualitas dari sistem informasi mendapat perhatian yang lebih baik, dibandingkan kualitas sistem dan kualitas layanan. Namun secara keseluruhan, dinilai sistem yang dibangun yaitu website company profile diterima dengan baik oleh pengguna.

7. Menggunakan sistem

Berikut adalah tampilan dari website company profile Look at Hijab yang dibangun guna tujuan utama sebagai sarana pemasaran UMKM dari Look at Hijab (Gambar 4). 


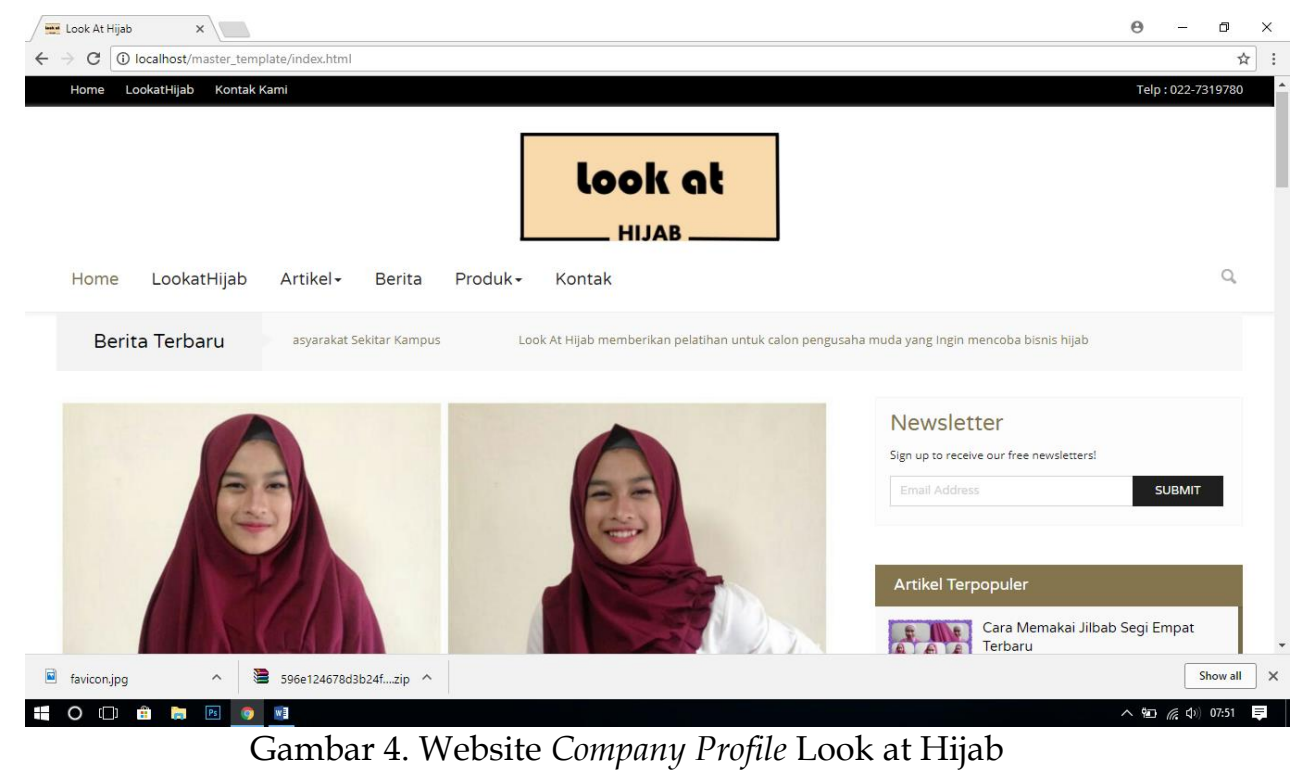

Seperti terlihat pada Gambar 4, desain web untuk website Company profile UMKM Look at Hijab cukup sederhana dan mudah dipahami konsumennya. Semua informasi tentang produk bisa ditampilkan di website tersebut dan info terkait mulai dari cara pemesanan barang dan info produk terbaru bisa dilihat juga via website. Dengan demikian para penghujung yang semula datang langsung bisa melihat hasil produk dari Look at Hijab melalui website. Melalui website company profile yang telah diciptakan, Look at Hijab telah memanfaatkan salah satu fasilitas ICT dan diharapkan melalui company profile, Look at Hijab sebagai salah satu UMKM di Kota Bandung dapat berkembang dan bersaing dengan lebih baik. Serta mendukung peningkatan perekonomian di Kota Bandung serta di Indonesia.

\section{Simpulan dan Rekomendasi}

Information Communication Technology (ICT) sangat penting dalam membantu perusahaan khususnya pada strategi pemasaran perusahaan. ICT pada Look at Hijab dibangun melalui website yaitu company profile. Melalui company profile, UMKM Look at Hijab mampu menyebarluaskan informasi baik produk dan perusahaan kepada masyarakat secara luas. Kajian dari pengbdian masyarakat pada Look at Hijab di Bandung memiliki keterbatasan, dimana belum dilakukan evaluasi dari aspek pemasaran. Mengingat aspek ini menjadi penting dalam mengevaluasi adanya strategi baru pada perusahaan (Wahyuniardi, Pribadi, Andriyanto, Nurjaman, \& Yunus, 2014). Hal ini menjadi rekomendasi dari kajian penelitian berikutnya atau pengabdian di Look at Hijab dari sisi pemasaran.

\section{Daftar Pustaka}

Al-Tabbaa, O., \& Ankrah, S. (2016). Social capital to facilitate "engineered" university-industry collaboration for technology transfer: A dynamic perspective. Technological Forecasting and Social Change, 104, 1-15. http://doi.org/10.1016/j.techfore.2015.11.027 
Aris, Saputra, I. B., Macario, K., Maulana, A., \& Mustaqim, F. (2015). Perancangan Media Company Profile Sebagai Penunjang Promosi Dan Informasi Pada PT. Pos Indonesia (PERSERO) TANGERANG 15000. In Seminar Nasional Teknologi Informasi dan Multimedia (Vol.3, pp. 6-8).

Aswati, S., Ramadhan, M. S., Firmansyah, A. U., \& Anwar, K. (2017). Studi Analisis Model Rapid Application Development Dalam Pengembangan Sistem Informasi. Jurnal Matrik, 16(2), 20-27.

Hasibuan, S. (2015). SMEs Development Strategy for Competitive and Sustainable Typical Local Snacks of Banten Province. International Journal on Advanced Science, Engineering and Information Technology, 5(6), 410-414.

Kapoor, S., \& Sandhu, H. S. (2010). Corporate Social Responsibility: A Case of Infosys Technologies Ltd. Asia Pacific Business Review, 6(2), 130-140. http:/ / doi.org/10.1177/097324701000600213

Krisbiantoro, D., Suyanto, M., \& Taufiqluthfi, E. (2015). Evaluasi Keberhasilan Implementasi Sistem Informasi dengan Pendekatan HOT FIT Model (Studi Kasus : Perpustakaan STMIK AMIKOM Purwokerto). In Konferensi Nasional Sistem E Informatika 2015 (pp. 9-10).

Pendong, L., Molenaar, R., Wullur, H., \& Pinatik, H. F. (2015). Pembuatan aplikasi ecommerce produk pertanian berbasis content management system (CMS). COCOS, 6(11), 1-9.

Pontoh, G. R. I., \& Lumenta, A. S. M. (2016). Arsip Digital Dokumen Kontrak Berbasis Web Pada PT. Abdi Pratama Perkasa. E-Journal Teknik Elelktro Dan Komputer, 5(4), 24-33.

Prasetyo, E. (2015). Rancang Bangun SistemInformasi Sekolah Tinggi Ilmu Ekonomi Rahmanyah Kabupaten Musi Banyuasin Berbasis Website. Jurnal Informatika, 1(2), 19-30.

Rahmi, D. Y., Rozalia, Y., Chan, D. N., Anira, Q., \& Lita, R. P. (2017). Green Brand Image Relation Model, Green Awareness, Green Advertisement, and Ecological Knowledge as Competitive Advantage in Improving Green Purchase Intention and Green Purchase Behavior on Creative Industry Products. Journal of Economics, Business $\mathcal{E}$ Accountancy Ventura, 20(2). http:/ / doi.org/10.14414/jebav.v20i2.1126

Reilly, A. H., \& Hynan, K. A. (2014). Corporate communication, sustainability, and social media: It's not easy (really) being green. Business Horizons, 57(6), 747-758. http:/ / doi.org/10.1016/j.bushor.2014.07.008 
Suhartanto, M. (2012). Pembuatan Website Sekolah Menengah Pertama Negeri 3 Delanggu Dengan Menggunakan Php Dan MySQL. Journal Speed - Sentra Penelitian Engineering Dan Edukasi, 4(1), 1-8.

Susilo, Y. S. (2010). Strategi meningkatkan daya saing UMKM dalam menghadapi implementasi CAFTA dan MEA. Buletin Ekonomi, 8(2), 70-78.

Urfa, V. H., Handayani, S. R., \& Hidayat, R. R. (2013). Efektifitas Penggunaan Kredit Program Kemitraan BUMN Terhadap Kinerja UMKM (Studi Kasus Pada Program Kemitraan PT. Telekomunikasi Indonesia, Tbk Sub Area Malang Untuk Industri Sari Apel Brosem Kota Batu). Jurnal Adminstrasi Bisnis, 6(1), 1-10.

Wahyuniardi, R., Pribadi, E. M., Andriyanto, B., Nurjaman, S., \& Yunus, M. (2014). Penyusunan Sistem Informasi Berbasis Web untuk Monitoring dan Evaluasi Sentra IKM Alas Kaki di Cibaduyut - Jawa Barat. In Seminar Nasional Teknik Industri BKSTI 2014 (pp. 25-30). http:/ / doi.org/10.13140/ RG.2.1.2073.9600 